\title{
PHARMACOKINETICS OF DANOFLOXACIN IN AFRICAN CATFISH (CLARIAS GARIEPINUS) AFTER INTRAVENOUS AND INTRAMUSCULAR ADMINISTRATIONS
}

\author{
Mohamed ABOUBAKR ${ }^{1 *}$ and Ahmed SOLIMAN ${ }^{2}$ \\ ${ }^{1}$ Pharmacology Department, Faculty of Veterinary Medicine, Benha University, \\ 13736 Moshtohor, Toukh, Qalioubeya, Egypt; ${ }^{2}$ Pharmacology Department, \\ Faculty of Veterinary Medicine, Cairo University, Egypt
}

(Received 28 March 2019; accepted 9 October 2019)

\begin{abstract}
The plasma pharmacokinetics of danofloxacin was studied in healthy African catfish (Clarias gariepinus) following a single intravenous (IV) and intramuscular (IM) administration of $10 \mathrm{mg} / \mathrm{kg}$ at $22{ }^{\circ} \mathrm{C}$. Catfish were divided into two groups (each group containing 78 fish), then danofloxacin mesylate $(10 \mathrm{mg} / \mathrm{kg})$ was administered IV (into the caudal vein) in Group 1 and IM (into the right epaxial muscle) in Group 2, and blood was obtained from the caudal vein before $(0 \mathrm{~h})$ and after $(0.25,0.5,1,2,4,8,12,24,36,48,72$ and $96 \mathrm{~h})$ of drug administration. High-performance liquid chromatography was used for the determination of plasma concentration, and a non-compartmental model was used for the analysis of pharmacokinetic parameters. After IV administration, elimination halflife $\left(\mathrm{t}_{1 / 2 \mathrm{~K}}, 24.49 \mathrm{~h}\right.$ ), mean residence time (MRT, $30.14 \mathrm{~h}$ ), volume of distribution at steady state $\left(\mathrm{Vd}_{\mathrm{ss}}, 1.07 \mathrm{~L} / \mathrm{kg}\right)$ and total body clearance $\left(\mathrm{CL}_{\mathrm{T}}, 0.035 \mathrm{~L} / \mathrm{h} / \mathrm{kg}\right)$ were determined. After IM administration, $\mathrm{t}_{1 / 2 \mathrm{~K} z}$, MRT, peak concentration $\left(\mathrm{C}_{\max }\right)$, time to reach $\mathrm{C}_{\max }$ and bioavailability were $47.64 \mathrm{~h}, 61.06 \mathrm{~h}, 5.22 \mu \mathrm{g} / \mathrm{mL}, 1 \mathrm{~h}$ and $67.12 \%$, respectively. After IM administration, danofloxacin showed good bioavailability and long $t_{1 / 2 k z}$. The favourable pharmacokinetic characteristics after IM administration support the use of danofloxacin for the treatment of susceptible bacterial infections in catfish.
\end{abstract}

Key words: Danofloxacin, catfish, bioavailability, pharmacokinetics, plasma

The raising of large numbers of fish in aquaculture has increased the risk of occurrence of bacterial diseases (Cabello, 2006; Canada-Canada et al., 2009; Miranda et al., 2018).

The African catfish (Clarias gariepinus) is one of the most important freshwater fishes and a fish commonly raised in aquaculture (Authman et al., 2013). Catfish has a high resistance to a wide range of pollutions, poor water quality, and oxygen depletion. It has commercial importance, being considered

*Corresponding author; E-mail: mohamed.aboubakr@fvtm.bu.edu.eg;

Phone: 0020-10 9987-4671; Fax: 0020-1324-63074 
one of the best alternatives to tilapia, and it is excellent for aquaculture as it is omnivorous and grows fast (Rad et al., 2004; Adewolu et al., 2008).

Antibiotics used to treat bacterial diseases in fish were not developed for these species, and dosages from other species were used for fish (Smith, 2008). Unsuccessful treatment, toxicity, drug residues and bacterial resistance development due to inaccurate dosage regimen are threats to public health (Capkin et al., 2015). Therefore, pharmacokinetic and pharmacodynamic parameters were used to estimate the efficacy of antimicrobial drugs and determine the suitable dosage regimen (Theuretzbacher, 2012).

In aquaculture, fluoroquinolones have been used to treat bacterial infections in fish (Brown, 1996). These compounds have broad-spectrum effects and are generally used for the treatment of skin, digestive, respiratory and urinary tract infections and septicaemia (Fadel et al., 2018). At low concentrations, they are effective against fish pathogens and provide excellent systemic distribution (Samuelsen, 2006; Samanidou and Evaggelopoulou, 2007).

Danofloxacin inhibits the bacterial DNA gyrase enzyme and has bactericidal activity (Dimitrova et al., 2014; Tian et al., 2019). It has antimicrobial activity against numerous Gram-negative and some Gram-positive bacteria and is recommended for the treatment of skin infections and septicaemia in fish (Fan et al., 2015; Corum et al., 2018). High bioavailability, long elimination half-life, good penetration into phagocytic cells, excellent tissue penetration and low plasma protein binding were specific features for danofloxacin (Giguere et al., 1996; Karademir et al., 2015).

The kinetics of danofloxacin was investigated in fish like tilapia (Fan et al., 2015) and brown trout (Corum et al., 2018). As there are hardly any data on the pharmacokinetics of danofloxacin in catfish, this study investigated the pharmacokinetics of danofloxacin in catfish after single intravenous (IV) and intramuscular (IM) administrations at a dose of $10 \mathrm{mg} / \mathrm{kg}$. The pharmacokinetic (PK) and pharmacodynamic (PD) parameters using PD data reported for susceptible pathogens were also determined.

\section{Materials and methods}

\section{Chemicals}

Danofloxacin (of analytical grade) was obtained from Sigma-Aldrich (St. Louis, MO, USA). Acetonitrile, triethylamine and orthophosphoric acid were obtained from Merck (Darmstadt, Germany) and Advocin ${ }^{\circledR} 2.5 \%, 25 \mathrm{mg} / \mathrm{mL}$ injectable solution from Pfizer Animal Health Division (Cairo, Egypt).

\section{Experimental fish}

Male African catfish (C. gariepinus) were obtained from the River Nile at Benha (body weight: $450 \pm 28 \mathrm{~g}$ ) and acclimatised for two weeks in 220-litre 
glass tanks $(100 \mathrm{~cm} \times 40 \mathrm{~cm} \times 55 \mathrm{~cm})$ containing tap water (temperature: $22.3 \pm$ $0.2{ }^{\circ} \mathrm{C}$; pH: $7.5 \pm 0.18$; dissolved oxygen: $6.5 \pm 0.70 \mathrm{mg} / \mathrm{L}$ ) and were fed on a commercial pellet diet (Skriting Egypt Company) and kept at a photoperiod of 12:12 light : dark). At three-day intervals, water in the tanks was siphoned off completely together with fish faeces and replaced with aerated tap water from a water storage tank. The study was approved by the Ethics Committee of the Faculty of Veterinary Medicine, Benha University, Egypt.

\section{Experimental design}

The catfish were divided into two groups (each group containing 78 fish), then danofloxacin mesylate $(10 \mathrm{mg} / \mathrm{kg}$ ) was administered IV (into the caudal vein) in Group 1 and IM (into the right epaxial muscle) in Group 2. Six fish were used at each sampling time. One $\mathrm{mL}$ blood was obtained under anaesthesia (tricaine methanesulphonate, $200 \mathrm{mg} / \mathrm{L})$ from the caudal vein, before $(0 \mathrm{~h})$ and after $(0.25$, $0.5,1,2,4,8,12,24,36,48,72$ and $96 \mathrm{~h}$ ) drug administration. Then the samples were collected into heparin-containing anticoagulant tubes, centrifuged for $10 \mathrm{~min}$ at $4000 \mathrm{~g}$, and plasma samples were obtained and stored at $-20^{\circ} \mathrm{C}$ until analysis.

\section{Analytical procedure}

The plasma concentrations of danofloxacin were measured using highperformance liquid chromatography (HPLC) (Shimadzu, Tokyo, Japan) (Corum et al., 2018). Acetonitrile $(200 \mu \mathrm{L})$ was added to plasma $(100 \mu \mathrm{L})$, vortexed $(1 \mathrm{~min})$, the mixture was centrifuged at $10,000 \mathrm{~g}$ for $10 \mathrm{~min}$, the supernatant was transferred to HPLC vials, and $10 \mu \mathrm{L}$ supernatant was injected into the HPLC. For chromatographic separation, a Gemini ${ }^{\mathrm{TM}} \mathrm{C}_{18}$ column $(250 \times 4.6 \mathrm{~mm}$; internal diameter: $5 \mu \mathrm{m}$; Phenomenex, Torrance, CA, USA) was used. The autosampler was at room temperature and the column temperature was maintained at $40{ }^{\circ} \mathrm{C}$. The mobile phase [acetonitrile and $0.4 \%$ orthophosphoric acid, including $0.4 \%$ triethylamine $(18: 82 \mathrm{v} / \mathrm{v})]$, was pumped into HPLC using a low-pressure gradient system at a flow rate of $1 \mathrm{~mL} / \mathrm{min}$. Ultraviolet-visible detection (SPD-10A) was set at $280 \mathrm{~nm}$ wavelength.

The calibration standards prepared for the plasma $(0-100 \mu \mathrm{g} / \mathrm{mL})$ were linear. The limits of quantitation and detection for the plasma were $0.04 \mu \mathrm{g} / \mathrm{mL}$. Quality control samples prepared for the plasma at $0.2,2$ and $20 \mu \mathrm{g} / \mathrm{mL}$ were used to determine recovery, which was $95.96,95.03$ and $94.18 \%$, respectively, and the intra- and inter-day coefficients of variation were $<5.13 \%$.

\section{Pharmacokinetic calculations}

Pharmacokinetic calculations were made using WinNonlin 6.1 (Pharsight Corporation, Scientific Consulting Inc., NC, USA). The PK parameters were assessed by non-compartmental model analysis. After IV administration, AUC, $\mathrm{t}_{1 / 2 \alpha z}$, 
MRT (AUMC/AUC), $\mathrm{CL}_{\mathrm{T}}$ (Dose/AUC) and $\mathrm{Vd}_{\mathrm{ss}}(\mathrm{Cl}$.MRT) in the plasma were determined, while for IM administration AUC, $\mathrm{t}_{1 / 2 \mathrm{~K} z}$, MRT and $\mathrm{F}=\mathrm{AUC}_{0-\infty \mathrm{IM}} /$ $\mathrm{AUC}_{0-\infty \mathrm{IV}} \times 100$ were calculated. Peak concentrations $\left(\mathrm{C}_{\max }\right)$ and $\left(\mathrm{T}_{\max }\right)$ of danofloxacin were determined via direct inspection of the plasma concentrationtime curve.

\section{Pharmacodynamic calculations}

The efficacy of danofloxacin depends on the $\mathrm{AUC}_{0-24} / \mathrm{MIC}$ and $\mathrm{C}_{\max } / \mathrm{MIC}$ ratios. The MIC of danofloxacin against bacteria isolated from catfish has not been determined yet. The MIC values of danofloxacin against bacteria isolated from other animal species were $\leq 0.5 \mu \mathrm{g} / \mathrm{mL}$ (Hannan et al., 1997).

\section{Results}

The plasma concentration-time curve and PK parameters after IV and IM administrations of danofloxacin at a single dose of $10 \mathrm{mg} / \mathrm{kg}$ in catfish are shown in Fig. 1 and Table 1, respectively. Danofloxacin showed lower AUC and longer plasma $\mathrm{t}_{1 / 2 \mathrm{z} z}$ and $\mathrm{MRT}_{0-\infty}$ after IM administration than after IV administration. After IV administration, $\mathrm{Vd}_{\mathrm{ss}}$ and $\mathrm{Cl}_{\mathrm{T}}$ were $1.07 \mathrm{~L} / \mathrm{kg}$ and $0.035 \mathrm{~L} / \mathrm{h} / \mathrm{kg}$, respectively.

After IM administration, $T_{\max }$ and $\mathrm{C}_{\max }$ were $1 \mathrm{~h}$ and $5.22 \mu \mathrm{g} / \mathrm{mL}$, respectively. The bioavailability was $67.12 \%$ after IM administration. Regarding the pharmacodynamics of danofloxacin, the $\mathrm{AUC}_{0-24} / \mathrm{MIC}$ and $\mathrm{C}_{\max } / \mathrm{MIC}$ ratios for pathogens with $0.5 \mu \mathrm{g} / \mathrm{mL}$ MIC were 140.38 and 10.45 , respectively, after IM administration of danofloxacin at a dose of $10 \mathrm{mg} / \mathrm{kg}$, while the $\mathrm{AUC}_{0-24} / \mathrm{MIC}$ and $\mathrm{C}_{\max } / \mathrm{MIC}$ ratios for susceptible pathogens with $0.5 \mu \mathrm{g} / \mathrm{mL}$ MIC were $<125$ and $<10$, respectively.

\section{Discussion}

After administrations of danofloxacin in catfish either by the IV or the IM route, no local or systemic side effects were detected. Similarly, following danofloxacin administration to tilapia and sea bass, no adverse effects were observed (Fan et al., 2015; Vardali et al., 2017).

Following IV administration of danofloxacin in catfish the $\mathrm{t}_{1 / 2 \mathrm{Kz}}$ was $24.49 \mathrm{~h}$. This figure was consistent with the data reported for flumequine $(24.6 \mathrm{~h})$ in catfish (Plakas et al., 2000), sarafloxacin (22.6 h) in silver crucian carp (Fang et al., $2016 b)$, was higher than that of enrofloxacin (17.44 h) in Korean catfish (Kim et al., 2006) and enrofloxacin (19.82 h) in snakehead fish (Fang et al., 2016a), and lower than that of enrofloxacin (63.5 h) in silver crucian carp (Fang et al., 2012).

After IV administration, danofloxacin showed good penetration and tissue distribution in catfish, as the $\mathrm{Vd}_{\mathrm{ss}}$ was $1.07 \mathrm{~L} / \mathrm{kg}$. This value was higher than that 
recorded for flumequine $\left(0.52 \mathrm{~L} \mathrm{~kg}^{-1}\right)$ in catfish (Plakas et al., 2000) and for enrofloxacin $\left(0.38 \mathrm{~L} \mathrm{~kg}^{-1}\right)$ in European cuttlefish (Gore et al., 2005), and lower than that determined for enrofloxacin $\left(3.93,3.40 \mathrm{~L} \mathrm{~kg}^{-1}\right)$ in Korean catfish and brown trout, respectively (Kim et al., 2006; Koc et al., 2009).

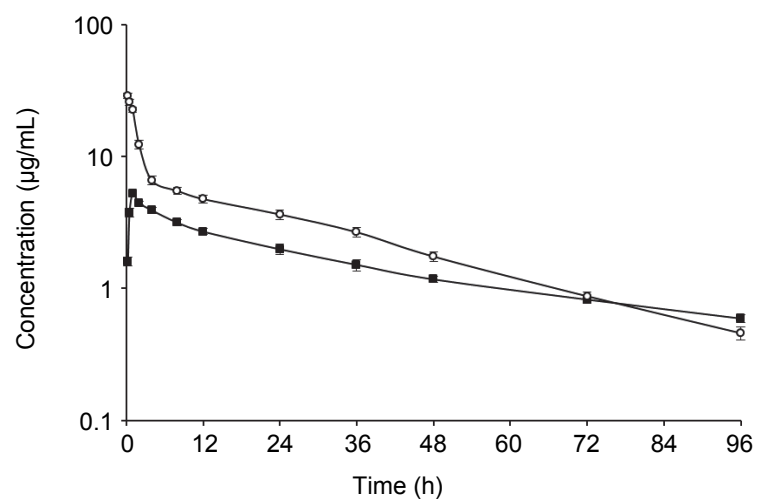

Fig. 1. Semi-logarithmic graph depicting the time-concentration of danofloxacin in the plasma of catfish after a single IV (०) and IM ( $(\mathbf{)})$ administration of $10 \mathrm{mg} / \mathrm{kg}$ body weight $(\mathrm{n}=6)$

\section{Table 1}

Plasma pharmacokinetic parameters of danofloxacin in catfish following IV and IM administration of $10 \mathrm{mg} / \mathrm{kg}$ body weight (mean $\pm \mathrm{SE} ; \mathrm{n}=6$ )

\begin{tabular}{|c|c|c|c|}
\hline Parameters & Unit & IV & IM \\
\hline$t_{1 / 2 \kappa z}$ & $\mathrm{~h}$ & $24.49 \pm 0.59$ & $47.64 \pm 3.66$ \\
\hline $\mathrm{AUC}_{0-24}$ & $\mu g \mathrm{~mL}^{-1} \mathrm{~h}^{-1}$ & $157.93 \pm 9.71$ & $70.19 \pm 3.41$ \\
\hline $\mathrm{AUC}_{0-96}$ & $\mu \mathrm{g} \mathrm{mL}^{-1} \mathrm{~h}^{-1}$ & $270.88 \pm 19.21$ & $148.15 \pm 8.16$ \\
\hline $\mathrm{AUC}_{0-\infty}$ & $\mu g \mathrm{~mL}^{-1} \mathrm{~h}^{-1}$ & $287.18 \pm 21.12$ & $189.16 \pm 11.55$ \\
\hline AUMC & $\mu \mathrm{g} \mathrm{mL}^{-1} \mathrm{~h}^{-2}$ & $8708.3 \pm 815.9$ & $11633.9 \pm 1029$ \\
\hline MRT & $\mathrm{h}$ & $30.14 \pm 0.63$ & $61.06 \pm 3.42$ \\
\hline $\mathrm{Vd}_{\mathrm{ss}}$ & $\mathrm{L} \mathrm{kg}^{-1}$ & $1.07 \pm 0.06$ & - \\
\hline $\mathrm{Cl}_{\mathrm{T}}$ & $\mathrm{L} \mathrm{kg}^{-1} \mathrm{~h}^{-1}$ & $0.035 \pm 0.002$ & - \\
\hline $\mathrm{C}_{\max }$ & $\mu \mathrm{g} \mathrm{mL}-1$ & - & $5.22 \pm 0.12$ \\
\hline $\mathrm{t}_{\max }$ & $\mathrm{h}$ & - & $1.00 \pm 0.00$ \\
\hline $\mathrm{F}$ & $\%$ & - & $67.12 \pm 5.45$ \\
\hline $\mathrm{AUC}_{0-24} / \mathrm{MIC}$ & Ratio & - & $140.38 \pm 6.83$ \\
\hline $\mathrm{C}_{\max } / \mathrm{MIC}$ & Ratio & - & $10.45 \pm 0.25$ \\
\hline
\end{tabular}

$\mathrm{t}_{1 / 2 K z}:$ elimination half-life; AUC: area under plasma concentration-time curve; AUMC: area under moment curve; MRT: mean residence time; $\mathrm{Vd}_{\mathrm{ss}}$ : volume of distribution at steady state; $\mathrm{Cl}_{\mathrm{T}}$ : total body clearance; $\mathrm{C}_{\max }$ : maximum plasma concentration; $\mathrm{t}_{\max }$ : time to peak plasma concentration; $\mathrm{F}$ : bioavailability; MIC: minimum inhibitory concentration

The total body clearance $\left(\mathrm{CL}_{\mathrm{T}}\right)$ was $0.035 \mathrm{~L} / \mathrm{kg} / \mathrm{h}$; this value was close to that reported for enrofloxacin $(0.04 \mathrm{~L} / \mathrm{kg} / \mathrm{h})$ in crucian carp (Fang et al., 2012), lower than that found for flumequine $(0.14 \mathrm{~L} / \mathrm{kg} / \mathrm{h})$ in catfish (Plakas et al., 2000) 
and for enrofloxacin $(0.14 \mathrm{~L} / \mathrm{kg} / \mathrm{h})$ in brown trout (Koc et al., 2009), for enrofloxacin in cuttlefish $(0.28 \mathrm{~L} / \mathrm{kg} / \mathrm{h}$; Gore et al., 2005), Korean catfish and brown trout $(0.137 \mathrm{~L} / \mathrm{kg} / \mathrm{h}$; Kim et al., 2006) and snakehead fish $(0.13 \mathrm{~L} / \mathrm{kg} / \mathrm{h}$; Fang et al., 2016a), as well as for sarafloxacin $(0.18 \mathrm{~L} / \mathrm{kg} / \mathrm{h})$ in silver crucian carp (Fang et al., 2016b).

Pharmacokinetic parameters were affected by size and environment $(\mathrm{pH}$, temperature and ion content), species differences, variation in dose, route of administration, age, and body condition (Intorre et al., 2000). In contrast to mammals, fish can adapt to low temperatures and adjust their biochemical and physiological functions based on their ambient temperature as they are heterothermic animals; thus, tissue perfusion and cardiac output depend on the ambient temperature in fish (Lees and Aliabadi, 2002).

Following IM administration, the elimination half-life $\left(\mathrm{t}_{1 / 2 \mathrm{~K}}\right)$ of danofloxacin was $47.64 \mathrm{~h}$, which is longer than that found for danofloxacin in brown trout (28.28 h; Corum et al., 2018) and shorter than that reported for enrofloxacin in crucian carp (80.95 h; Shan et al., 2018). Maximal plasma concentration $\left(\mathrm{C}_{\max }\right)$ was $5.22 \mu \mathrm{g} / \mathrm{ml}$, achieved at a $\mathrm{t}_{\max }$ of $1 \mathrm{~h}$. These values were similar to that of danofloxacin $(4.79 \mu \mathrm{g} / \mathrm{ml})$ achieved at $1 \mathrm{~h}$ in brown trout (Corum et al., 2018).

The bioavailability of danofloxacin in catfish was $67.12 \%$. This value indicated a moderate absorption of danofloxacin from catfish muscles. It was consistent with that previously reported for danofloxacin in brown trout $(55.99 \%$; Corum et al., 2018). Fluoroquinolones are non-ionised and amphoteric (pKa: 6.2 and 9.4) at $\mathrm{pH}$ 6-8 (Brown, 1996). So the penetration of danofloxacin into fish muscle could be considered sufficient at a pH of 7 (Gatica et al., 2010). Freshwater fish use the skin and the gills for osmoregulation; thus, following IM administration, drugs can also be eliminated via the skin. In fish, intramuscularly administered drugs have also been recorded to seep through the injection channel (Wilkie et al., 2006). Also, the bioavailability of drugs in fish was shown to be affected by water temperature (Corum et al., 2018). These differences in bioavailability may be related to water chemistry ( $\mathrm{pH}$, ion content), which are regarded as important factors in the stability of drugs. Also, chelation with cations occurred as a result of ionisation at higher $\mathrm{pH}$, and the bioavailability of quinolones was reported to be lower in seawater than in freshwater (Intorre et al., 2000; Kim et al., 2006).

The efficacy of antibacterial drugs based on concentration is calculated by the $\mathrm{C}_{\max } / \mathrm{MIC}$ and $\mathrm{AUC} / \mathrm{MIC}$ ratios. For the prevention of antibacterial resistance and for effective treatment, $\mathrm{AUC} / \mathrm{MIC}>125$ and $\mathrm{C}_{\max } / \mathrm{MIC}>10$ were recommended (Miravitlles, 2005; Theuretzbacher, 2012). The MIC value of danofloxacin for bacteria isolated from catfish has not been estimated, but those of danofloxacin against pathogens with $0.5 \mu \mathrm{g} / \mathrm{mL}$ MIC were 140.38 and 10.45 , respectively ( $\mathrm{Lu}, 2006)$. The $\mathrm{AUC}_{0-24} / \mathrm{MIC}$ and $\mathrm{C}_{\max } / \mathrm{MIC}$ ratios for susceptible pathogens were $<125$ and $<10$, respectively. 
In conclusion, IM administration of danofloxacin in catfish exhibited longer $\mathrm{t}_{1 / 2 z}$ and moderate bioavailability. After IM administration of danofloxa$\operatorname{cin}(10 \mathrm{mg} / \mathrm{kg})$ in catfish, the values of $\mathrm{AUC}_{0-24} / \mathrm{MIC}>125$ and $\mathrm{C}_{\max } / \mathrm{MIC}>10$ would be expected to successfully treat catfish infected by strains with MIC values $\leq 0.5 \mu \mathrm{g} / \mathrm{mL}$. Further studies are needed to determine the in vitro and in vivo antibacterial efficacy of danofloxacin against pathogens isolated from catfish.

\section{References}

Adewolu, M. A., Adeniji, C. A. and Adejobi, A. B. (2008): Feed utilization, growth and survival of Clarias gariepinus (Burchell 1822) fingerlings cultured under different photoperiods. Aquaculture 283, 64-67.

Authman, M. M., Abbas, W. T., Abumourad, I. M. and Kenawy, A. M. (2013): Effects of illegal cyanide fishing on vitellogenin in the freshwater African catfish, Clarias gariepinus (Burchell, 1822). Ecotoxicol. Environ. Saf. 91, 61-70.

Brown, S. (1996): Fluoroquinolones in animal health. J. Vet. Pharmacol. Ther. 19, 1-14.

Cabello, F. C. (2006): Heavy use of prophylactic antibiotics in aquaculture: a growing problem for human and animal health and for the environment. Environ. Microbiol. 8, 1137-1144.

Canada-Canada, F., Munoz de la Pena, A. and Espinosa-Mansilla, A. (2009): Analysis of antibiotics in fish samples. Anal. Bioanal. Chem. 395, 987-1008.

Capkin, E., Terzi, E. and Altinok, I. (2015): Occurrence of antibiotic resistance genes in culturable bacteria isolated from Turkish trout farms and their local aquatic environment. Dis. Aquat. Organ. 114, 127-137.

Corum, O., Durna Corum, D., Er, A., Terzi, E. and Uney, K. (2018): Plasma and tissue disposition of danofloxacin in brown trout (Salmo trutta fario) after intravenous and intramuscular administrations. Food. Addit. Contam. Part A 35, 2340-2347.

Dimitrova, D., Haritova, A., Dinev, T., Moutafchieva, R. and Lashev, L. (2014): Comparative pharmacokinetics of danofloxacin in common pheasants, guinea fowls and Japanese quails after intravenous and oral administration. Br. Poult. Sci. 55, 120-125.

Fadel, A., Mabrok, M. and Aly, S. (2018): Epizootics of Pseudomonas anguilliseptica among cultured seabream (Sparus aurata) populations: Control and treatment strategies. Microb. Pathog. 121, 1-8.

Fan, Y. C., Sheu, S. Y., Lai, H. T., Chang, M. H., Chen, P. H., Lei, Y. C., Kuo, T. F. and Wang, C. Y. (2015): Residue depletion study of danofloxacin in cultured tilapia (Oreochromis mossambicus). J. AOAC Int. 98, 575-579.

Fang, X., Liu, X., Liu, W. and Lu, C. (2012): Pharmacokinetics of enrofloxacin in allogynogenetic silver crucian carp, Carassius auratus gibelio. J. Vet. Pharmacol. Ther. 35, 397-401.

Fang, X., Zhou, J. and Liu, X. (2016a): Pharmacokinetics of enrofloxacin in snakehead fish, Channa argus. J. Vet. Pharmacol. Ther. 39, 209-212.

Fang, X., Zhou, J. and Liu, X. (2016b): Pharmacokinetics of sarafloxacin in allogynogenetic silver crucian carp, Carassius auratus gibelio. Fish. Physiol. Biochem. 42, 335-341.

Gatica, M., Monti, G., Knowles, T. and Gallo, C. (2010): Muscle pH, rigor mortis and blood variables in Atlantic salmon transported in two types of well-boat. Vet. Rec. 166, 45-50.

Giguere, S., Sweeney, R. and Belanger, M. (1996): Pharmacokinetics of enrofloxacin in adult horses and concentration of the drug in serum, body fluids, and endometrial tissues after repeated intragastrically administered doses. Am. J. Vet. Res. 57, 1025-1030. 
Gore, S., Harms, C., Kukanich, B., Forsythe, J., Lewbart, G. and Papich, M. (2005): Enrofloxacin pharmacokinetics in the European cuttlefish, Sepia officinalis, after a single i.v. injection and bath administration. J. Vet. Pharmacol. Ther. 28, 433-439.

Hannan, P., Windsor, G., De Jong, A., Schmeer, N. and Stegemann, M. (1997): Comparative susceptibilities of various animal-pathogenic mycoplasmas to fluoroquinolones. Antimicrob. Agents Chemother. 41, 2037-2040.

Intorre, L., Cecchini, S., Bertini, S., Varriale, A. C., Soldani, G. and Mengozzi, G. (2000): Pharmacokinetics of enrofloxacin in the seabass (Dicentrarchus labrax). Aquaculture 182, 49-59.

Karademir, U., Boyacioglu, M., Kum, C. and Sekkin, S. (2015): Comparative pharmacokinetics of enrofloxacin, danofloxacin and marbofloxacin following intramuscular administration in sheep. Small Ruminant Res. 133, 108-111.

Kim, M. S., Lim, J. H., Park, B. K., Hwang, Y. H. and Yun, H. I. (2006): Pharmacokinetics of enrofloxacin in Korean catfish (Silurus asotus). J. Vet. Pharmacol. Ther. 29, 397-402.

Koc, F., Uney, K., Atamanalp, M., Tumer, I. and Kaban, G. (2009): Pharmacokinetic disposition of enrofloxacin in brown trout (Salmo trutta fario) after oral and intravenous administrations. Aquaculture 295, 142-144.

Lees, P. and Aliabadi, F. S. (2002): Rational dosing of antimicrobial drugs: animals versus humans. Int. J. Antimicrob. Agents 19, 269-284.

Lu, T. Y. (2006): The assessment of danofloxacin used against Amur sturgeon infected by Aeromonas hydrophila [Dissertation]. Northeast Agricultural University, Harbin, China.

Miranda, C. D., Godoy, F. A. and Lee, M. R. (2018): Current status of the use of antibiotics and the antimicrobial resistance in the Chilean salmon farms. Front. Microbiol. 9, 1284.

Miravitlles, M. (2005): Moxifloxacin in respiratory tract infections. Expert Opin. Pharmacother. 6, 283-293.

Plakas, S. M., El Said, K. R. and Musser, S. M. (2000): Pharmacokinetics, tissue distribution, and metabolism of flumequine in channel catfish (Ictalurus punctatus). Aquaculture 187, 1-14.

Rad, F., Kurt, G. and Bozaogul, A. S. (2004): Effects of spatially localized and dispersed patterns of feed distribution on the growth, size dispersion and feed conversion ratio of the African catfish (Clarias gariepinus). Turk. J. Vet. Anim. Sci. 28, 851-856.

Samanidou, V. F. and Evaggelopoulou, E. N. (2007): Analytical strategies to determine antibiotic residues in fish. J. Sep. Sci. 30, 2549-2569.

Samuelsen, O. B. (2006): Pharmacokinetics of quinolones in fish: a review. Aquaculture 255, 55-75.

Shan, Q., Fan, J., Wang, J., Zhu, X., Yin, Y. and Zheng, G. (2018): Pharmacokinetics of enrofloxacin after oral, intramuscular and bath administration in crucian carp (Carassius auratus gibelio). J. Vet. Pharmacol. Ther. 41, 159-162.

Smith, P. (2008): Antimicrobial resistance in aquaculture. Rev. Sci. Tech. 27, 243-264.

Theuretzbacher, U. (2012): Pharmacokinetic and pharmacodynamic issues for antimicrobial therapy in patients with cancer. Clin. Infect. Dis. 54, 1785-1792.

Tian, E., Chen, C., Hu, W., Miao, Y., Muhammad, I., Zhang, Q., Liu, Y., Xu, L., Bao, J., Ding, L. and Li, J. (2019): Population pharmacokinetics for danofloxacin in the intestinal contents of healthy and infected chickens. J. Vet. Pharmacol. Ther. 42, 556-563.

Vardali, S., Kotzamanis, Y., Tyrpenou, A. and Samanidou, V. (2017): Danofloxacin depletion from muscle plus skin tissue of European sea bass (Dicentrarchus labrax) fed danofloxacin mesylate medicated feed in seawater at $16^{\circ} \mathrm{C}$ and $27^{\circ} \mathrm{C}$. Aquaculture 479, 538-543.

Wilkie, M. P., Morgan, T. P., Galvez, F., Smith, R. W., Kajimura, M., Ip, Y. K. and Wood, C. M. (2006): The African lungfish (Protopterus dolloi): ionoregulation and osmoregulation in a fish out of water. Physiol. Biochem. Zool. 80, 99-112. 